\title{
PLASTICIDAD DEL SISTEMA NERVIOSO
}

\author{
L. M. Garcia-Segura *
}

Eil problema de la plasticidad morfologica y funcional del sistéma nervioso ha atraido la atencion de numerosos investigadores desde hace mucho tiempo. Este concepto es utilizado por los investigadores y por los clinicos que se preocupan del problema de la regeneración de funciones en el sistéma nervioso ${ }^{45}$. También ha servido, en el siglo pasado, para elaborar teorias sobre la memoria y el funcionamiento del cerebro ${ }^{38}$. Actualmente sabemos algo más que entonces sobre lo que en realidad consiste la "plasticidad" neuronal y muchas de aquellas teorías no estan de acuerdo con nuestros conocimientos actuales. Sin embargo hoy, con nuestros nuevos conceptos sobre la plasticidad, podemos explicar una parte del funcionamento del sistéma nervioso.

Sabemos actualmente que las neuronas presentan ciertos grados de plasticidad morfologica, fisiologica y molecular. La intención de este trabajo es la de dar una visión de conjunto sobre los ultimos descubrimientos en este campo.

Plusticidud morfologica - Son ya clasicas las experiencias realizadas en la Universidad de Berkeley que demonstraron que. cuanto mayor es el número de estimulaciones que recibe un animal mayor será el peso de su corteza cerebral $1,4,40$. Más recientemente se ha demonstrado que las neuronas de la corteza visual y del cuerpo geniculado lateral presentan mayor o menor número de dendritas, de ramificaciones dendriticas y de espinas dendriticas según que los animales reciban más o menos estimulaciones luminosas $3,10,14,15,35,41,44,83$. Igualmente se ha demostrado que en las ratas privadas de lúz se produce una disminución en el número de sinapsis en ciertas capas de la corteza visual $\mathrm{y}$ en el núcleo geniculado lateral $4,11$.

En ratas privadas de aferencias somáticas o visuales se produce un aumento en el número de espinas dendriticas de las neuronas de la corteza au ditiva. Esto puede ser interpretado como una consecuencia del uso mayor que la rata ciega o sin tacto hace del sentido de la audición y por consiguiente de los centros auditivos ${ }^{42}$.

Todas estas experiencias demuestran que el desarrollo morfológico del cerebro continua tras el nacimiento $y$ es influido por la información que recibe. Pero ademas, las modificaciones morfológicas de las neuronas frente a las estimulaciones que llegan a ellas estan asociadas a modificaciones fisiológicas y bioquímicas.

Instituto Cajal, C.S.I.C., Madrid, España. 
Plasticidad fisiológica - Hoy en dia está generalmente admitido y así se puede leer en muchos líbros de fisiología y de psicología fisiológica, que los reflejos monosinápticos estan más facilitados cuanto más utilizados hayan sido. Como se sabe, este concepto proviene de los trabajos de Eccles y sus colaboradores 8, 9. Eccles, fundandose en sus propias experiencias, ha elaborado la teoría de que el uso favorece la transmisión sináptica Por el contrario esta puede estar disminuida por la falta de uso ?.

Otro fenómeno de plasticidad fisiológica es la habituación de los reflejos medulares. Puede encontrarse bastante información critica sobre las experiencias de Eccles y sobre la habituación en Thompson ${ }^{46}$.

Recientemente numerosas experiencias han demonstrado la existencia de una plasticidad fisiológica en las neuronas del sistéma visual de algunos animales en ciertas etápas de su vída. Anteriormente hemos visto como numerosos estudios recientes, que parten fundamentalmente de los trabajos de Valverde ${ }^{49}, 50$, han demostrado que la morfología de las neuronas del sistéma visual puede variar como respuesta a las estimulaciones que las neuronas reciben. También han sido realizadas experiencias fisiológicas en el sistéma visual que nos enseñan como la fisiología de las neuronas puede variar frente a los estímulos que reciben del medio. Estos trabajos han demonstrado que el campo receptor de las neuronas varía según los estímulos que a ellas llegan Las neuronas de la corteza visual son binoculares y responden a un amplio margen de estimulos en condiciones normales, sin embargo puede conseguirse que no respondan nada más que a las estimulaciones de un solo ojo, o bien que su campo receptor varie con respecto a la retina, si las primeras experiencias visuales del animal se alteran convenientemente $2,12,22,24,36,37,47,52$. Un reciente trabajo ${ }^{5}$ ha demonstrado que esta plasticidad fisiológica acontece tambien en los animales adultos. Al mismo tiempo que estas alteraciones fisiológicas de las neuronas, como consecuencia de una información visual más pobre que lo normal, se encuentran tambien alteraciones en el comportamiento ${ }^{34}$.

Queda por determinar cual es la base de esta plasticidad fisiológica de las neuronas. Podemos suponer que existe una degeneración de ciertas conexiones preestablecidas genéticamente, manteniendose solo las utilizadas. Otra posibilidad es que ocurra la creación de nuevas conexiones Una tercera alternativa es que no exista variación en las conexiones entre las neuronas, si no en la funcionalidad de las sinapsis, for ejemplo por una alteración en la biosíntesis del transmisor sináptico. 51

Plasticidad molecular - La existencia de una plasticidad molecular en el sistéma nervioso como adaptación o como respuesta a las condiciones cambiantes del medio es un hecho que comienza a aclararse.

Muchos trabajos han demonstrado la existencia de diferencias histoquímicas entre neuronas de un mismo tipo ${ }^{13}, 18,19,32,34$. Esto parece apoyar la hipótesis de que existen diferencias en el estado metabólico entre unas neuronas y otras, probablemente asociadas con el estado fisiológico de actividad, o lo que es lo mismo, con la estimulación o la ausencia de estimulación reciente. Hydén demostró que las neuronas privadas de estimulos presentaban un contenido 
más pobre de RNA que las neuronas que recibian una estimulación normal 81, 25. Ademas ha sido demostrada la ocurrencia de un cambio en la composición de las bases del RNA durante el aprendizaje $26 \_31,43,44$.

Actualmente hay bastantes evidencias de que el sistéma RNA-proteinas interviene en el proceso de codificación de la memoria ${ }^{16,17}$. Las neuronas activas tienen una biosíntesis proteica más rapida que las neuronas en reposo ${ }^{39}$. Ademas se han encontrado cambios en el metabolismo proteico de las neuronas como resultado de la estimulación. Estas experiencias han demonstrado que la adquisición de información se acompaña de un incremento en la biosíntesis de RNA y de proteinas ${ }^{16}$. Estas proteinas pueden tener varios papeles ${ }^{14}$ entre los que se encuentra precisamente el de acumular la información adquirida.

En 1967 se comunicó que había sido posible transferir información de una rata a otra inyectando extractos del cerebro de la primera en la segunda ${ }^{20}$. Estas experiencias fueron repetidas muchas veces y Ungar llegó, tras un largo trabajo, a asislar la molécula responsable de este fenómeno que resultó ser un polipeptido ${ }^{48}$. Como la información transferida fué la de huir de la oscuridad el polipeptido fué denominado escotofobina. La estructura de la escotofobina ha sido ya descifrada y su efecto ha sido verificado en muchos animales y en numerosas ocasiones ${ }^{16,17}$. El hecho de que la información pueda codificarse en polipeptidos es una prueba de lo que supone la plasticidad molecular del cerebro. El sistéma nervioso es capaz de adaptarse al medio extreno mediante la biosíntesis de polipeptidos que guardan la información y que ordenan las respuestas apropriadas cuando se produce una situación similar a la original.

Hasta aquí hemos visto como la plasticidad del sistéma nervioso se manifiesta tanto a nivel morfológico y fisiológico como a nivel molecular.

La experiencia puede modificar el metabolismo proteico, produciendo la biosintesis de proteinas que codifican la información y que regulan el comportamiento futuro.

El campo receptor de las neuronas varía tambien en respuesta a la experiencia, ya sea por modificación morfológica de sus dendritas, o bien por la modificación funcional de sus sinápsis. Las neuronas se adaptam morfologica y fisiologicamente conforme a las estimulaciones que reciben. A fin de cuentas son capaces de exhibir una plasticidad biológica Como consecuencia de esta plasticidad tienen lugar muchos fenómenos que son estudiados por los psicólogos.

Uno de estos fenómenos es el aprendizaje Cuando se produce en los mecanismos que regulan la plasticidad un defecto, ocurre una alteración patológica.

\section{RESUMEN}

En este trabajo se revisan los conocimientos más recientes sobre el fenómeno de la plasticidad del sistéma nervioso, tanto a nivel morfológico como a nivel fisiológico y molecular. Se estudian los cambios morfólogicos y fisiológicos 
de las neuronas frente a la experiencia Tambien se considera la adaptación molecular del sistéma nervioso a la información que recibe como la base de todo típo de plasticidad.

\section{SUMMARY}

\section{Plasticity of the nervous system: a review}

The most recent knowledge about the phenomenon of the nervous system plasticity are revised, as much in morphological as in physiological and molecular levels. The neuron morphological and physiological changes opposite to the experience are studied. The nervous system molecular adaptation to the information it receives as the base of all type of plasticity is also considered.

\section{REFERENCIAS}

1. BENNETT, E. L.; DIAMOND, M. C.; KRECH, D. \& ROSENZWFIG, M. R. Chemical and anatomical plasticity of brain. Science 146:610, 1964.

2. BLAKEMORE, C. \& MITCHELL, D. E. - Environmental modification of the visual cortex and the neural basis of learning and memory. Nature 241:467, 1973.

3. COLFMAN, P. D. \& RIESEN, A. H. - Environmental efects on cortical dendritic fields. J. Anat. 102:365, 1968.

4. CRAGG, B, G. - The effects of vision and dark-rearing on the size and density of synapses in the lateral geniculate nucleus mesured by electron microscopy. Brain Res. 13:53, 1969.

5. CREUTZFELDT, O. D. \& HEGGELUND, P. - Neuronal plasticity in visual cortex of adult rats after exposure to visual patterns. Science 188:1025, 1975.

6. DIAMOND. M. C.; LAW, F.; RHODES, H.; LINDER, B.; ROSENZWEIG. M. R.; KRENCII, D. \& BENNETT, E. I. - Increases in cortical depth and glia numbers in rats subjected to enriched environment. J. Comp. Neurol. 128:117, 1966.

7. ECCIES. J. C. - The nature of central inhibition. Proc. Roy. Sic. Section B. 153:445, 1961.

8. ECCLES, J, C. \& MCINTYRE, A. K. - The effects of the use and of inartivity of mammalian spinal reflexes. J. Physiol. 121:492, 1963.

9. ECCLES, R. M. \& WESTERMAN, R.A. - Enhanced synaptic function due to excesive use. Nature 184:460, 1969.

10. FIFKOVA, E. - Changes in the visual cortex of rats after unllateral deprivalion. Nature 220:379, 1968.

11. FIFKOVA, E. - The effect of monocular deprivation on the synaptic contarts of the visual cortex. J. Neurobiol. 1:285, 1970.

12. FREFMAN, R. D. \& PETTIGREW, J. D. - Alteration of visual rortex from environmental asymetrles. Nature 246:359, 1973.

13. GARCtA-SFGURA, L. M. - The use of tannin-iron method as a nervous system general stain technique. Trab. Inst. Cajal 66, 1974.

14. GARCfA-SEguRA, L. M. - Cambios estructurales en el cerebro frente a la experlencia y su relación con la memoria y el aprendizaje. Arch. Neurohiol. $37: 561,1974$.

15. GARCiA-SEguRA, L. M. - Regulación ejercida por la experiencia en el desarrollo cerebral: revisión. Rev. Psiquiatría y Psicología Medica 12:49. 1975.

16. GARCIA-SFGIRA, L. M. -. La base molerular de la memoria y el aprendizaje. Rev. Neurologia 3:73. 1975. 
17. GARCIA-SEguRA, I. M. - Papel de las proteinas en la memoria. Arch. Neurohlol. 1975. En prensa.

18. GARCIA-SE, GuRA, I. M. \& DIAZ-r,ONZAt,EZ, P. - Etude sur le sperificité histochimique de la méthode tanno-ferrique, Ann. Histochim. 20:173. 1975.

19. GARCIA-SFGURA, L. M.: MARTINEZ-RODRIGUEZ, R.; TOLEDANO, A.; de AGUSTIN, M. \& RODRIGUEZ-GONZALEZ, C. -- Investigación histoquímica de fosfolípicios y esteres triglicéridos simples en rcrebelo de reta. Trab). Inst. Cajal 66. 1974.

20. GAY, R. \& RAPHELSON, A. - "Transfer of learning" by injection or brain RNA: a replication. Psychonomir Scl. 8:369, 1967.

21. HAMBERGER, C, A. \& IYYDFN, II. -- Produrtion of nucleoproteins in the vestibular ganglion. Arta olo-laring. Suppl. 75:53, 1949.

22. HIRsCH, II. V. B. \& SINEILI, D, N, - Visual experience morlifies distributinn of horizontally and vertically oriented receptive fields in cats. Sriphic 1968:869. 1970 .

23. MIRSCH, 11, V, B. \& SPINELLI, D, N. - Modifiration of the distribution of receptive field orientation in rats by selective visual exposure during develnpment. Exp. Brain Res. 12:509, 1971.

24. HUBEI, D. II \& WIESFL, T. N. - The period of susceptibility to the physiological effects of unilateral eye closure in kittens. J. Physiol. (London) 206:419. 1970.

25. HYDEN, IH. - Satellite cells in the nervous system. Sri. Am. 205:62, 1961.

26. HYDFN, H, \& FGYHAZI, F. - Nuclear RNA rhanges of nerve rells during a learning experiment in rats. Proc. Nat. Acad. Sri. (Washington) 48:1366, 1962.

27. HYDEN, H. \& EGYHAZI. E. - Glial RNA changes during a learning experiunent. in rats. Proc. Nat. Acad. Sci. (Washington) 49:618, 1963.

28. HYDEN, H. \& EGYHAZI, F. - Changes in RNA content and base inmpnsilinn in cortical neurons of rats in a learning experiment involving transfer of handedness. Proc. Nat. Acral. Sri. (Washington) 52:1030, 1964.

29. HYDEN, H. \& IANGE, P. W. -- A differentiation in RNA response in neurons early and late during learning. Proc. Nat. Acad. Sci. (Washington) 53:946. 1965.

30. HYDEN, H. \& LANGE, P. W. - A genic stimulation with production of adenineuracil rich RNA in neurons and glia in learning. Naturwiss. 53:64, 1966.

31. HYDEN, H.; LANGE, P. W.; MIHAILOVIC, J. J. \& PETROVIC-MINIC, B. Changes of RNA base composition in nerve cells of monkeys subjected to visunl discrimination and delayed alternation performance. Brain Res. 65:215, 1974.

32. MARTINEZ-RODRIGUEZ, R.; GARCIA-SEGURA, I, M.; TOIEDANO, $\Lambda$.: (;ONZALEZ, M.; GAMONAL, A.; DE AGUSTIN, M.; DIAZ-GONZALEZ, 6 . \& RODRIGUEZ-GONZALEZ, C. - Investigation of acid mucosubstances in rat cerebellum. Ann. Historhim. 20, 1975.

33. MARTINEZ-RODRIGUEZ, R.; TOLEDANO, A.; GARCIA-SEGURA. I., M .; GONZAI.EZ, M.; GAMONAL, A.; DIAZ-GONZALEZ, P.; DE AGUSTIN, M. \& RODRIGUEZ-GONZALEZ, C. - Mucopolysarcharicles in hypothalamic neurons of the rat. J. Anat. 1975, en prensa.

34. MUIR, D. W. \& MITCHELL, D. E, - Behavioral delicits in cals following carly selerted visual exposure to contours of a single orlentation. Brain Res. 85:459, 1975.

35. PARNAVELAS. J. G.; GLOBUS, A. \& KAUPS, P. - Changes in lateral geniculate neurons of rats as a result of continuous exposure to light. Nature now biol. 245:287, 1973.

36. PETTIGREW, J. D.; OLSON, C. \& BARLOW, H. B. - Kitten visual crirtex: shortterm stimulus-induced changes in connectivity. Science 180:1212. 197.3.

37. PETTIGREW, J, D.; OLSON, C. \& HIRSCH, H. V. B. - Cortical cifect uf s.. lective visual experience: degeneration or renganization? Brain isis $51: 31.5$, 1973.

38. RAMON Y CAJAT, S. - Histongie du Systeme Nerveux de lilumme ut lies Vertébrés, Vol. 2. C. S. T. C. Institulu Cajal. Mathid: 1972. 
39. ROSE, S. P. R. - Changes in visual cortex on first exposure of rats to light. Nature 215:253, 1967.

40. ROSENZWEIGH, M. R.; BENNETT, E. L. \& DIAMOND, M. C. - Brain changes in response to experience. Sci. Am. 226:22, 1972.

41. RUIZ-MARCOS, A. \& VALVERDE, F. - The temporal evolution of the distribution of dendritic spines on the visual cortex of normal and dark raised mice Exp. Brain Res. 8:284, 1969.

42. RYUGO, D. K.; RYUGO, R.; GLOBUS, A. \& KILLAKEY, H. P. - Increased spine density in auditory cortex following visual or somatic deafferentiation Brain Res. 90:143, 1975.

43. SHASHOVA, V. E. - RNA changes in goldfish brain during learning. Nature $217: 238,1968$.

44. SHASHOVA, V. E. - RNA metabolism in goldfish brain during acquisition of new behavioral patterns. Proc. Nat. Acad. Sci. (Washington) 65:160, 1970.

45. STEIN, D. G.; ROSEN, J. J. \& BUTTERS, N. - Plasticity and recovery of function in the central nervous system. Academic Press, New York, 1974.

46. THOMPSON, R. F. - Fundamentos de Psicologia Fisiológica. Versáo castelhana. Editorial Trillas, México, 1974.

47. TRETTER, F.; CYNADER, M. \& SINGER, W. - Modification of direction selectivity of neurons in the visual cortex of kittens. Brain Res. 84:143, 1975.

48. UNGAR, G. - Evidence for molecular coding of neural information. In $\mathbf{H}$. $\mathbf{P}$. Zippel (Ed.) - Memory and Transfer of Informatinon. Plenum Press. New York, 1973.

49. VALVERDE, F. - Apical dendritic spines of the visual cortex and light deprivation in the mouse. Exp. Brain Res. 3:337, 1967.

50. VALVERDE, F. - Rate and extent of recovery from dark rearing in the visual cortex of the mouse. Brain Res, 33:1. 1971.

51. VAN HOF, M. W. - Retinal input and early development of the visual system. Docum. ophthal (Den Haag) Proc. Series, 4:495, 1974.

52. VAN SLUYTERS, R. C. \& BLAKEMORE, C. - Experimental creation of unsual neuronal properties in visual cortex of kitten. Nature, 246:506, 1973.

53. VOLKMAR, F. R. \& GREENOUGH, W. T. - Rearing complexity affects branching of dendrites in the visual cortex of the rat. Science 176:1445, 1972.

Instituto Cajal C. S. I. C. - Calle Velazquez, 144-Madrid-6 - España. 